\title{
Tectonic implications of post-folding Permian magnetizations in the Carapacha Basin, La Pampa province, Argentina
}

\author{
Renata N. Tomezzoli ${ }^{1,2}$, Ricardo N. Melchor ${ }^{1,3}$, and William D. MacDonald ${ }^{4}$ \\ ${ }^{1}$ CONICET_Consejo Nacional de Investigaciones Científicas y Técnicas \\ ${ }^{2}$ Universidad de Buenos Aires, F.C.E. y N., Departamento de Ciencias Geológicas, Pab. II., Ciudad Universitaria. C1428EHA, CABA, Argentina \\ ${ }^{3}$ Universidad Nacional de La Pampa, Av. Uruguay 151, 6300 Santa Rosa. La Pampa, Argentina \\ ${ }^{4}$ State University of New York, Binghamton, NY 13902-6000, USA
}

(Received February 9, 2006; Revised June 5, 2006; Accepted June 6, 2006; Online published November 8, 2006)

\begin{abstract}
Paleomagnetic results from Permian clastic and igneous rocks of the Carapacha Basin of the Gondwáides orogenic zone of central Argentina are mainly consistent with results reported previously from the same zone further east, e.g., in the Sierra de la Ventana. Three lithologic entities were analysed: the lower member and upper member of the Carapacha Formation, and an andesite intrusive into the upper member. The directions of their characteristic remanences are similar, differ significantly from the present field direction, and are post-folding. The in situ magnetization directions are moreover consistent with directions expected for late Permian poles of the APWP for South America. The in situ pole for the lower Carapacha Formation is $70^{\circ} \mathrm{S}, 049^{\circ} \mathrm{E}, \mathrm{A} 95=11^{\circ}(\mathrm{San}$ Roberto pole); the pole for the upper Carapacha, combined with similar directions from the intrusive, is $64^{\circ} \mathrm{S}$, $005^{\circ} \mathrm{E}, \mathrm{A} 95=5^{\circ}$ (Río Curacó pole). These magnetizations imply that the Carapacha Formation, with a minimum age of early Late Permian (about $260 \mathrm{Ma}$.), was deformed before the end of the Permian. Structural evidence, as well as paleomagnetic, IRM, and AMS experimental results, support the interpretations. The paleogeographic implications of these results are interpreted as a significant counterclockwise movement of Gondwana between the early and the late Permian.
\end{abstract}

Key words: Gondwana, Carapacha Basin, South America, Late Paleozoic, paleomagnetism, magnetic anisotropy, AMS.

\section{Introduction}

Following a paleomagnetic study of the Sierra de la Ventana (Fig. 1) fold and thrust belt (Tomezzoli and Vilas, 1999; Tomezzoli, 2001), we are extending our studies westward into rocks of similar Late Paleozoic age in the Carapacha Basin, La Pampa province, Argentina (Figs. 1 and 2). The studied area is known as "SamFrau geosyncline" (Du Toit, 1927) or "Gondwánides" orogenic belt (Keidel, 1916; Fig. 1). Although Ramos (1984) hypothesized a suture zone between the South America craton and Patagonia terranes, the hypothesized collision event is unproven and there are many alternative tectonic interpretations for the deformation of this belt (Dalmayrac et al., 1980; Ramos, 1984; Japas, 1989; Sellés Martinez, 1989; Cobbold et al., 1992; Tomezzoli, 2001). The study of the Tunas Formation, from Sierra de la Ventana near the eastern end of this zone, yielded a distinctive variation in the age of folding relative to remagnetization. (Tomezzoli and Vilas, 1999; Tomezzoli, 2001).

Investigation of the fabric of the Cerro de los Viejos Complex (Tomezzoli et al., 2003), located close to the Carapacha Basin (Fig. 1), revealed two distinct foliations, s1 and $\mathrm{s} 2$. The primary foliation $\mathrm{s} 1$ formed during the main

Copyright (c) The Society of Geomagnetism and Earth, Planetary and Space Sciences (SGEPSS); The Seismological Society of Japan; The Volcanological Society of Japan; The Geodetic Society of Japan; The Japanese Society for Planetary Sciences; TERRAPUB. deformation in the area, which has been dated between $280.4 \pm 2.3 \mathrm{Ma}$ and $261 \pm 13 \mathrm{Ma}$ (Tickyj, 1999). The age of the secondary foliation s 2 is less clear.

The objectives of the current work are: comparing paleomagnetic results along the Argentine portion of this deformed belt; improving the APWP of the late Paleozoicearly Mesozoic for South America, and establishing the age of the deformation regionally to evaluate time - transgressive deformation. A preliminary paleomagnetic study in the upper Carapacha yielded a late syntectonic or postectonic magnetization (Tomezzoli and Melchor, 1997). The paleomagnetic pole (PP) calculated from these preliminary results is: Lat.: $60^{\circ} \mathrm{S}$, Long.: $7^{\circ} \mathrm{E}, \sigma p=16$ and $\sigma m=12$, consistent with that presented in this paper.

\section{Geological Setting}

The Carapacha Basin is a continental half-graben of Permian age located in southern La Pampa province, central Argentina (Melchor, 1995, 1999; Fig. 1). This basin lies west of the Late Paleozoic Sauce Grande basin (Sierra de la Ventana). The basin filling is up to $630 \mathrm{~m}$ thick and entirely composed of clastic deposits of the Carapacha Formation. The base of the formation is not exposed. The upper part of the formation is intruded by andesite assigned to El Centinela Formation and believed to be associated with Permian-Triassic volcanic rocks of the Choiyoi Group. Basement rocks include Upper Cambrian to Lower Devonian metamorphic rocks (Las Piedras Metamorphic Com- 


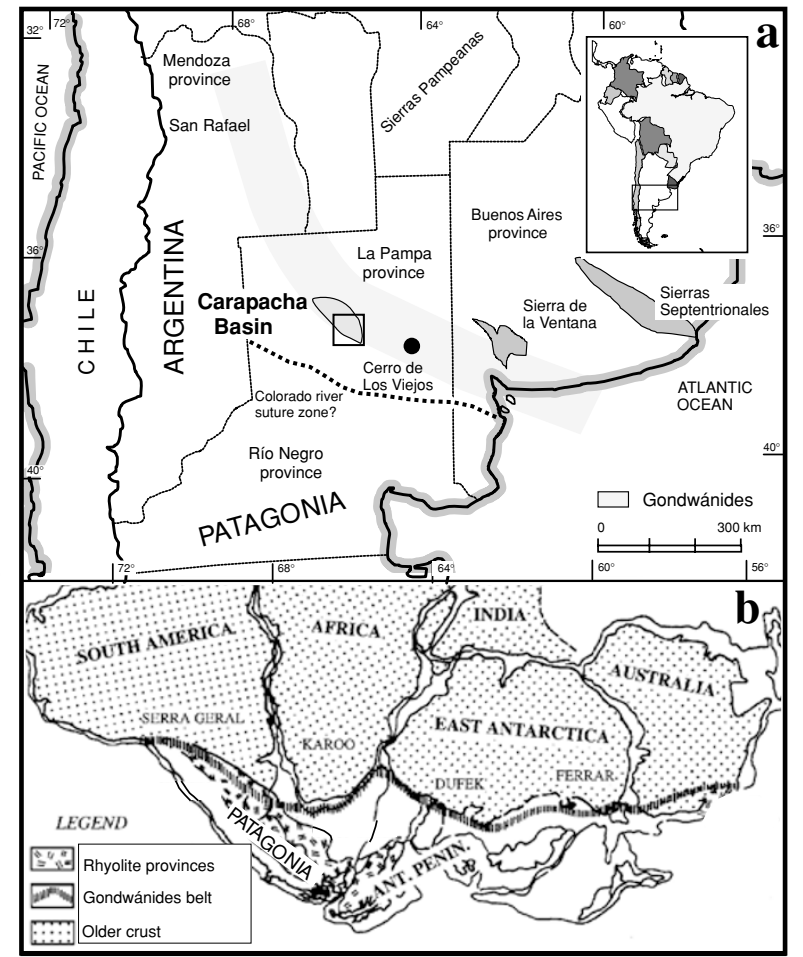

Fig. 1. a) Location of the Paleozoic sample localities in the Carapacha Basin (frame); b) deformed orogenic belt known as "Gondwánides belt" (Keidel, 1916) in Argentina (modified from Kay et al., 1989).

plex), granitoids (Pichi Mahuida Group), and Late Paleozoic granite orthogneisses (Cerro de los Viejos Complex) that outcrop in southeastern La Pampa province (Tickyj et al., 1999).

Red and gray arkosic or lithic sandstones, mudstones and scarce conglomerates compose the Carapacha Formation. It has been divided into two members separated by an unconformity (Fig. 3): the lower Calencó Member and the upper Urre-Lauquen Member (Melchor, 1999). The formation has yielded a typical Permian Glossopteris macroflora (Melchor and Césari, 1991, 1997). More specifically, the taphoflora from the lower member has been dated as late Early Permian and that from the upper member as early Late Permian (Melchor and Césari, 1991, 1997). The succession of the basin is dominated by fluvial facies with subordinate lacustrine deposits (Fig. 3). The lower Carapacha outcrops at the Estancia San Roberto locality make up a homoclinal succession striking $\mathrm{N} 40^{\circ} \mathrm{E}$ and dipping $40^{\circ} \mathrm{NW}$. Poor exposure precludes a more definite determination of the tectonic structure here. The rocks of the upper Carapacha along Río Curacó are gently folded, showing two scales of folds: mega-folds (wave length $1.1 \mathrm{~km}$ ) and mesofolds (wave length $1-3 \mathrm{~m}$ ). The axial plane of the megafolds strikes $\mathrm{N} 310^{\circ}$ and dips $20^{\circ} \mathrm{NE}$. The strike of the axial plane of the mesofolds is bimodal: the largest population displays an average orientation of $\mathrm{N} 55^{\circ} \mathrm{E}$, and the other is roughly coincident with the trend of megafolds (average $\mathrm{N} 52^{\circ} \mathrm{W}$ ). In addition, strike-slip, normal and reverse faults and extensional veins are also present.

The structure and weak deformation of the upper Carapacha Formation at Río Curacó was interpreted as reflec-

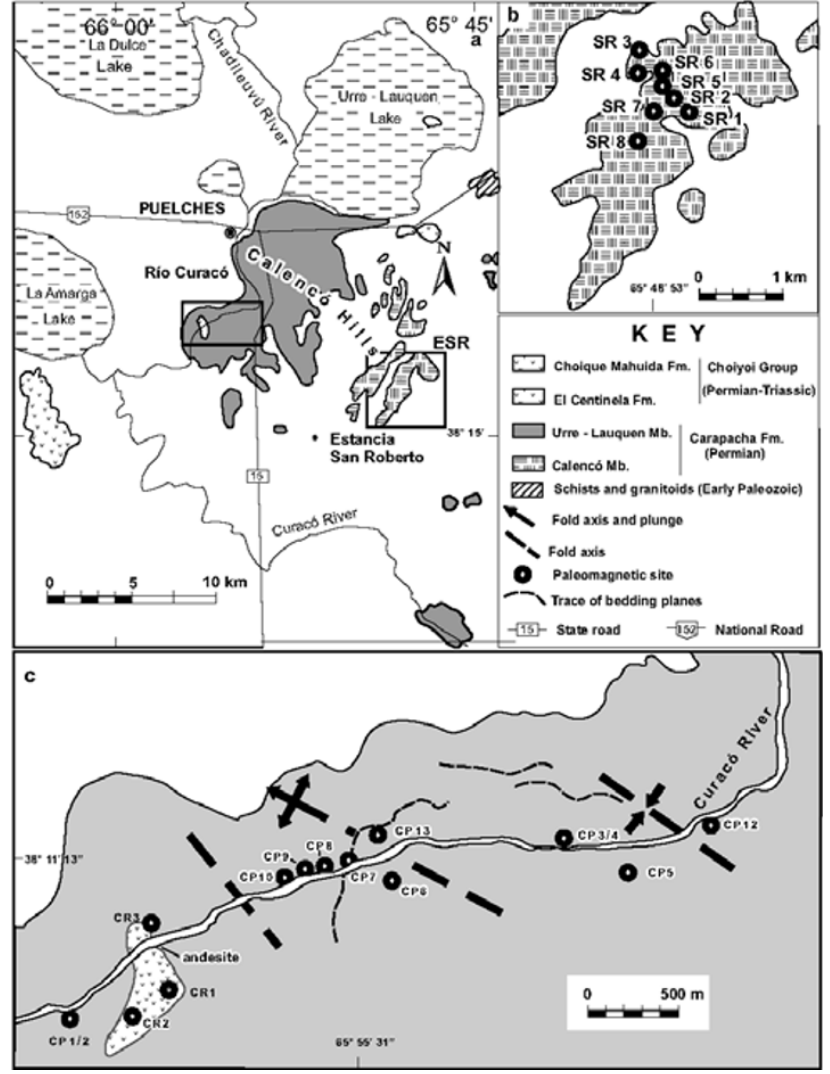

Fig. 2. Setting of study area. a) Main outcrop areas in the Carapacha Basin, south-central La Pampa province (see also Fig. 1a). b) Paleomagnetic sample sites of the lower Carapacha Formation, in the Estancia San Roberto (SR) locality; location of this map is shown by rectangle labelled ESR in Fig. 2a. c) Paleomagnetic sample sites of the upper Carapacha Formation are coded by CP near the Curacó River (RC); the andesite sample sites are coded CR; location of this map is shown by a rectangle in Fig. 1a.

ting left-lateral strike-slip deformation under a transpressive regime (Melchor, 1995). The mean orientation of the associated shear zone is $\mathrm{N} 60^{\circ} \mathrm{W}$ as suggested by the array of the structural elements, including left-lateral strike-slip faults. This transpressive deformation is associated with cessation of sedimentation in the basin (Melchor, 1995). The samples studied are mudstones, siltstones and fine grained sandstones. Mudstones and siltstones are red, brown or gray, massive or laminated and contain $2 \%$ to $15 \%$ opaque minerals. The petrography was described by Melchor (1995). The dominant opaque minerals are fine-grained hematite, followed by leucoxene, rare pyrite and magnetite. The sandstones are dominantly red or purple arkosic arenites, in which plagioclase is commonly the most abundant feldspar. Arkosic wackes and lithic arenites are subordinate. Hematite content in sandstones varies from less than $1 \%$ to $9 \%$ and averages about 3\% (Melchor, 1995). The andesite samples from La Represa vicinity are porphyritic with abundant altered phenocrysts of plagioclase, amphibole and biotite, in a microgranular groundmass (Linares et al., 1980).

The units sampled and the sampling areas south of Puelches (Fig. 2) are as follows: lower Carapacha Formation (Calencó Member; $38^{\circ} 13.5^{\prime} \mathrm{S}, 65^{\circ} 48^{\prime} \mathrm{W}$ ), at Estancia 


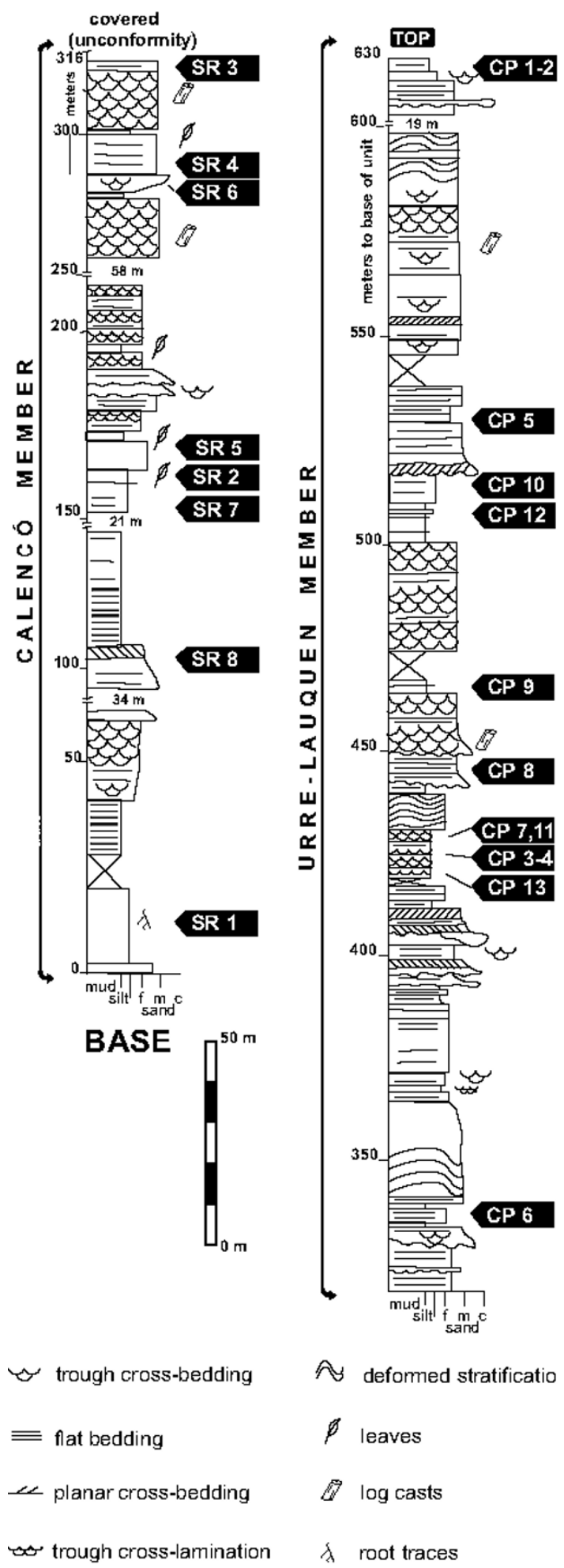

Fig. 3. Stratigraphic distribution of paleomagnetic sites through the lower and upper members of the Carapacha Formation (see also Table 1). Column modified after Melchor (1995, 1999).

(farm) San Roberto (ESR); upper Carapacha Formation (Urre- Lauquen Member), and an andesite intrusive into the upper Carapacha Formation along the Rio Curacó (RC; $\left.38^{\circ} 11.6^{\prime} \mathrm{S}, 65^{\circ} 55.8^{\prime} \mathrm{W}\right)$. The andesitic intrusive is assigned to El Centinela Formation of the Choiyoi Group. This intrusion has yielded a K/Ar age of $242 \pm 10$ Ma (Linares et al., 1980) i.e., latest Permian to early Triassic. Else- where, El Centinela Formation has yielded a ${ }^{40} \mathrm{Ar} /{ }^{39} \mathrm{Ar}$ laser fusion age of 236.6 $\pm 1.0 \mathrm{Ma}$ (Melchor and Llambías, 2000). These dates suggest that the peak of the Gondwanic eruptive activity in this region ocurred at about 240 Ma, i.e. early Triassic. The Carapacha Formation is commonly intruded by small rhyolitic dikes that are assigned to the Choique Mahuida Formation. Rapela et al . (1996) reported a $\mathrm{Rb} / \mathrm{Sr}$ isochron date of $240 \pm 2 \mathrm{Ma}$ for rhyolites of the Choique Mahuida Formation (Choiyoi Group) from the neighboring Lihuel Calel range. The great regional distribution and sparse radiometric age-control of these PermoTriassic eruptive units necessarily results in large uncertainties in their relative as well as absolute ages and regional correlations.

\section{Laboratory Procedures}

Three localities (Fig. 2 and Table 1) were sampled. Except for La Represa (LR), which is smaller, each locality is about $4 \mathrm{~km}^{2}$ in area; samples span the entire exposed section of the Carapacha Formation (Fig. 3). At Río Curacó, the upper Carapacha was sampled in multiple folds and at San Roberto the lower Carapacha was sampled in an homoclinal sequence. A minimum of four hand samples or six drill cores were collected per site, at sixteen (including three sites in the andesite) and eight sites respectively. Samples were oriented in the field using magnetic and/or sun compasses. Typically three standard cylindrical specimens $(2.2$ $\mathrm{cm}$ long. $\times 2.5 \mathrm{~cm}$ diameter) were cut from each core. Measurements of natural remanent magnetization (NRM) were made using a DC squid cryogenic magnetometer ( $2 \mathrm{G}$ model 750R). Pilot samples were subjected to stepwise alternating field (A.F.) demagnetization in 15 steps, up to $140 \mathrm{mT}$. This method proved effective in demagnetizing only some of the specimens. Thermal demagnetization was more successful, and was applied in at least 15 steps, with maximum temperatures of $680^{\circ} \mathrm{C}$, using an ASC TD model 48 oven with dual chambers. Bulk susceptibility was measured in some of the specimens after each step to monitor possible chemical changes during heating, with a Bartington MS2 susceptibility meter. Isothermal remanence acquisition (IRM) experiments were performed by applying increasing magnetic fields in successive steps, reaching fields of $1000 \mathrm{mT}$. Demagnetization results were analyzed using orthogonal vector plots (Zijderveld, 1967) and stereographic projections. Paleomagnetic directions were determined using principal component analysis (Kirschvink, 1980) or using the remagnetization planes technique (Halls, 1976). The final site mean directions were compiled using Fisher (1953) statistics, or in the case of combined directional data and remagnetization great circles, the method of McFadden and McElhinny (1988) was used. Anisotropy of magnetic susceptibility (AMS) was measured to evaluate the degree of deformation of the rocks using a Kappabridge KLY-2 (Geofyzika Brno) apparatus to obtain the magnitude and orientations of the susceptibility axes Kmax, Kint and Kmin.

\section{Paleomagnetic Results from the Lower Cara- pacha Formation at Estancia San Roberto}

Studies were conducted on 92 specimens (from 37 cores and 9 hand samples), from 8 sites of the lower Cara- 
Table 1. Site-mean high temperature characteristic directions in the Carapacha Basin. N/n: Number of processed specimens/number of specimens used in the calculation of the mean; (n) number of great circles. Dec.: Declinations (deg); Inc.: Inclinations (deg); $\alpha 95$ (deg)=semi-angle of the 95 per cent confidence cone; k: Fisher statistical parameter (Fisher, 1953). Bedding: strike and dip (right hand rule). * paleomagnetic data from these sites were rejected. SR: 8 sites, 92 specimens (from 37 cores and 9 hand samples). RC: 13 sites, 120 specimens (from 67 cores and 16 hand samples). LR: 3 sites, 22 specimens (from 21 cores).

\begin{tabular}{|c|c|c|c|c|c|c|c|c|c|c|}
\hline Site & $\mathrm{N} / \mathrm{n}$ & Dec. $^{\circ}$ & Inc. $^{\circ}$ & $\alpha 95^{\circ}$ & $\mathrm{k}$ & Bedding & Dec. $^{\circ}$ & Inc. $^{\circ}$ & $\alpha 95^{\circ}$ & $\mathrm{k}$ \\
\hline \multicolumn{7}{|c|}{ in situ } & \multicolumn{4}{|c|}{ with bedding correction } \\
\hline \multicolumn{6}{|c|}{ Estancia San Roberto. Lower Carapacha } & \multicolumn{5}{|c|}{100 per cent unfolding } \\
\hline Sr1 & $16 / 7(7)$ & 146 & 53 & 6 & 43 & $254 / 40$ & 052 & 78 & 6 & 43 \\
\hline $\mathrm{Sr} 2$ & $12 / 12$ & 155 & 39 & 3 & 237 & $245 / 45$ & 156 & 84 & 3 & 237 \\
\hline Sr3 & $11 / 5$ & 353 & -42 & 9.5 & 65 & $242 / 38$ & 215 & 73 & 9.5 & 65 \\
\hline $\mathrm{Sr} 4 *$ & 11 & - & - & - & - & $263 / 36$ & - & - & - & - \\
\hline $\operatorname{Sr} 5 *$ & 12 & - & - & - & - & $250 / 40$ & - & - & - & - \\
\hline Sr6* & 8 & - & - & - & - & $240 / 34$ & - & - & - & - \\
\hline Sr7 & $14 / 6$ & 156 & 55 & 7 & 104 & $250 / 55$ & 346.5 & 70 & 7 & 104 \\
\hline Sr8 & $8 /(4)$ & 166 & 40 & 11 & 241 & $238 / 33$ & 190 & 69 & 11 & 241 \\
\hline Mean & $5 / 8$ & 160 & 46 & 10 & 59 & & 206 & 87 & 17 & 21 \\
\hline \multicolumn{6}{|c|}{ Río Curacó. Upper Carapacha } & \multicolumn{5}{|c|}{100 per cent unfolding } \\
\hline $\mathrm{CP} 1$ & $5 /(5)$ & 148 & 57 & 10 & 124 & $136 / 21$ & 173 & 48 & 10 & 124 \\
\hline $\mathrm{CP} 2$ & $8 / 5$ & 129 & 67 & 11.5 & 45 & $146 / 17.5$ & 170 & 66 & 11.5 & 45 \\
\hline $\mathrm{CP} 3$ & $8 / 3(5)$ & 131 & 66 & 6 & 78.5 & $313 / 19$ & 95.5 & 59 & 6 & 78.5 \\
\hline $\mathrm{CP} 4 *$ & $8 / 3(5)$ & 095 & 64.5 & 4 & 206 & $313 / 19$ & 75 & 50 & 4 & 206 \\
\hline CP5 & $8 /(7)$ & 140.5 & 70 & 5 & 201 & $297 / 33$ & 65 & 59.5 & 5 & 201 \\
\hline CP6 & $11 / 10$ & 155 & 63 & 6 & 70.5 & $278 / 08$ & 144 & 69 & 6 & 70.5 \\
\hline $\mathrm{CP} 7$ & $12 / 6(3)$ & 145.5 & 54 & 5 & 126 & $159 / 08$ & 157 & 55 & 5 & 126 \\
\hline CP8 & $8 /(8)$ & 152.5 & 67.7 & 5 & 145 & $208.5 / 9.5$ & 172 & 75 & 5 & 145 \\
\hline $\mathrm{CP} 9$ & $9 / 9$ & 145 & 65 & 5 & 125 & $143 / 11$ & 167 & 62 & 5 & 125 \\
\hline CP10 & $8 / 7$ & 141 & 58 & 9 & 46 & $189 / 22$ & 181 & 69 & 9 & 46 \\
\hline CP11* & $11 /(9)$ & 130 & 40 & 6 & 98 & $242 / 34$ & 101 & 68 & 6 & 98 \\
\hline CP12 & $13 / 4(9)$ & 157 & 56 & 6 & 57 & $122.5 / 19$ & 173.5 & 43 & 6 & 57 \\
\hline CP13* & $10 / 4$ & 001 & -63 & 5.5 & 275 & $163 / 5$ & 93 & 71 & 5.5 & 275 \\
\hline \multirow[t]{2}{*}{ Mean } & $10 / 13$ & 145 & 63 & 4 & 132 & & 153 & 65 & 12 & 16.5 \\
\hline & \multicolumn{5}{|c|}{ Andesite } & & & & & \\
\hline $\mathrm{Cr} 1$ & $9 / 6(1)$ & 140 & 51 & 8 & 60 & & & & & \\
\hline $\mathrm{Cr} 2$ & $7 / 5(2)$ & 154 & 56 & 5 & 126 & & & & & \\
\hline $\mathrm{Cr} 3$ & $6 / 4(2)$ & 150 & 53 & 6 & 306 & & & & & \\
\hline \multirow[t]{2}{*}{ Mean } & $3 / 3$ & 148 & 53 & 8 & 263 & & & & & \\
\hline & Río & uracó + & Indesi & & & & & & & \\
\hline Mean & $16 / 13$ & 146 & 60.5 & 4 & 114 & & & & & \\
\hline
\end{tabular}

pacha Formation. Natural remanent magnetizations are near $300 \pm 200 \mathrm{~mA} \mathrm{~m}^{-1}$ in sites $\mathrm{Sr} 1, \mathrm{Sr} 5$ and $\mathrm{Sr} 7,80 \mathrm{~mA}$ $\mathrm{m}^{-1}$ in $\mathrm{Sr} 8,40 \mathrm{~mA} \mathrm{~m}^{-1}$ in $\mathrm{Sr} 2$ and Sr6, and less than 20 $\mathrm{mA} \mathrm{m} \mathrm{m}^{-1}$ in $\mathrm{Sr} 3$ and $\mathrm{Sr} 4$.

In most samples it was possible to isolate one component in the southeast quadrant (in situ) with positive inclination (Table 1) and good within-site groupings $\left(\alpha 95<15^{\circ}\right.$ and $\mathrm{k}>20$ ). This component is referred to as Population 1. For those remanence directions which were stable during heating, with a gradual decay to the origin (Fig. 4a), unblocking temperatures reached up to $680^{\circ}$, showing that this magnetization is carried by hematite (Fig. 5a). In other samples, demagnetization paths were curved along great circles, indicating simultaneous removal of distinct magnetic components with overlapping unblocking temperatures (Fig. 4aa). Unblocking temperatures of these samples ranged from $550^{\circ}$ to $580^{\circ} \mathrm{C}$, suggesting that the magnetization is carried by magnetite or titanomagnetite. The experiments of IRM acquisition showed that the main carriers of the remanence are hematite (indicated by the lack of saturation; Fig. 5a), and in less proportion magnetite (SR303B;
Fig. 5a) which saturates in the higher fields. The Mrs values are quite low, typical of sedimentary rocks with hematite carriers of remanence. As the proportion of ferromagnetic minerals such as magnetite increases, the Mrs likewise increases correspondingly (Dunlop and Özdemir, 1997).

In Sr3, remanence components have only negative inclination and are nearly antipodal to components at other sites (Sr1, Sr2, Sr7 and Sr8; see Table 1). Sites Sr4, Sr5 and Sr6 have no internal consistency or some cores have internally consistent specimen directions but the isolated component has no obvious geological meaning. For this reason, paleomagnetic data from these three sites were rejected. A second low temperature component between $100^{\circ} \mathrm{C}$ and $400^{\circ} \mathrm{C}$ was isolated in some specimens (Fig. 4aa), with negative inclinations (in situ), and dispersed directions. The low unblocking temperatures and the scattered distribution indicate that this component is a secondary magnetization probably of recent vintage. Consequently, it is not considered relevant for tectonic interpretations.

Unfolding was applied to the Population 1 vectors (Table 1). The in situ mean direction (Fig. 6a) is: D. $=160^{\circ}$, 

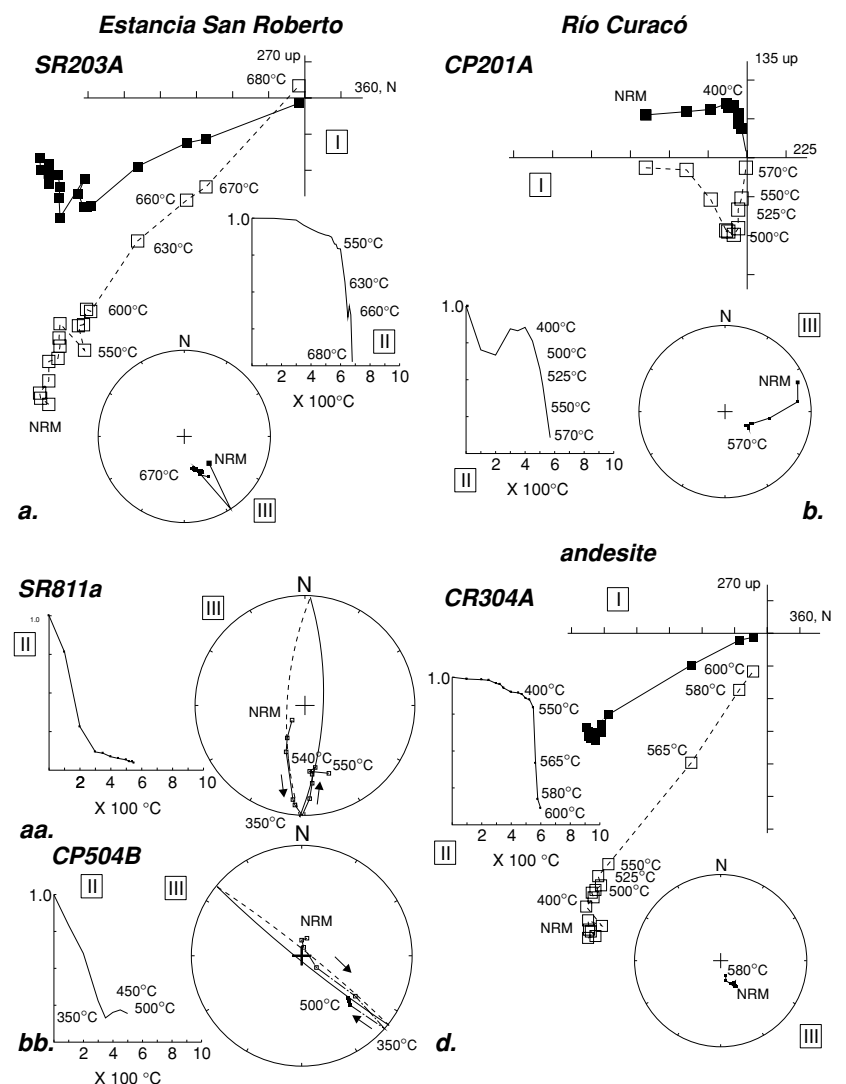

Fig. 4. Representative thermal demagnetization results for selected specimens. a) lower Carapacha Formation, Estancia San Roberto; b) and c) upper Carapacha Formation, along Río Curacó; d) the andesite. I: Zijderveld diagrams. Open (filled) squares indicate vertical (horizontal) plane projections, in geographic coordinates. II: Demagnetization curves. III: Equal-area projection. In 4c, a remagnetization circle is shown.

$\mathrm{I} .=46^{\circ}, \alpha 95=10^{\circ}, \mathrm{k}=59, \mathrm{~N}=5$. After full bedding correction $(100 \%)$ the mean direction is: $\mathrm{D} .=206^{\circ}, \mathrm{I} .=87^{\circ}$, $\alpha 95=17^{\circ}$ and $\mathrm{k}=21$ (Fig. 6b). These results suggest that the magnetization of the lower Carapacha is postfolding at $99 \%$ level of confidence (McFadden, 1990). The direction-correction tilt test (Enkin, 2003) yields a negative fold test with an optimal untilting at $-68.72 \pm 113.05 \%$ untilting (Fig. 7a).

\section{Paleomagnetic results from the upper Cara- pacha Formation at Rio Curacó}

Studies were conducted on about 120 specimens (from 67 cores and 16 hand samples) of the upper Carapacha Formation, sampled at 13 sites. Natural remanent magnetization ranges from 0.2 to $5 \mathrm{~mA} \mathrm{~m}^{-1}$. All specimens exhibited similar behavior during progressive demagnetization.

Most specimens were quite stable during the early heating steps up to $550^{\circ} \mathrm{C}$. At higher temperatures directions became unstable. Decay paths were linear to the origin (Fig. 4b), or curved along great circles towards the southeast quadrant with positive inclination, indicating simultaneous removal of distinct magnetic components with overlapping unblocking temperatures (Fig. 4bb). Unblocking temperatures varied from $450^{\circ}$ to $580^{\circ} \mathrm{C}$, suggesting that the magnetization is carried by magnetite. The experiments of

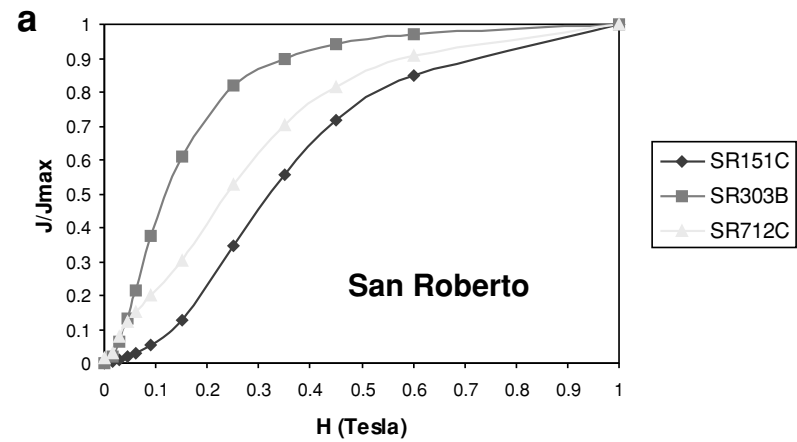

Specimen Susc. (m3/kg) Mrs. (Am2/kg) Mrs/Susc. $\begin{array}{llll}\text { SR151C } & 8.46 \mathrm{E}-08 & 6.58 \mathrm{E}-08 & 7.77 \mathrm{E}-01\end{array}$

SR303B 5.28E -08 $1.78 \mathrm{E}-07 \quad 3.38 \mathrm{E}+00$

$\begin{array}{llll}\mathrm{SR} 712 \mathrm{C} & 1.14 \mathrm{E}-07 & 3.84 \mathrm{E}-08 & 3.37 \mathrm{E}-01\end{array}$

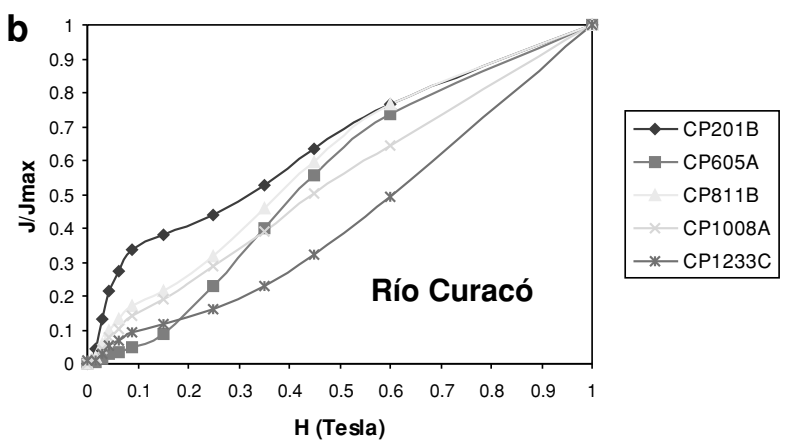

$\begin{array}{lrrr}\text { Specimen } & \text { Susc. }(\mathrm{m} 3 / \mathrm{kg}) & \mathrm{Mrs} .(\mathrm{Am} 2 / \mathrm{kg}) & \mathrm{Mrs} / \mathrm{Susc} . \\ \text { CP 201B } & 7.11 \mathrm{E}-08 & 6.57 \mathrm{E}-08 & 9.25 \mathrm{E}-01 \\ \text { CP 605A } & 5.63 \mathrm{E}-08 & 7.96 \mathrm{E}-08 & 1.41 \mathrm{E}+00 \\ \text { CP } 811 \mathrm{~B} & 7.43 \mathrm{E}-08 & 4.78 \mathrm{E}-08 & 6.44 \mathrm{E}-01 \\ \text { CP } 1008 \mathrm{~A} & 5.23 \mathrm{E}-08 & 8.95 \mathrm{E}-08 & 1.71 \mathrm{E}+00 \\ \text { CP } 1233 \mathrm{C} & 9.42 \mathrm{E}-08 & 5.26 \mathrm{E}-08 & 5.58 \mathrm{E}-01\end{array}$

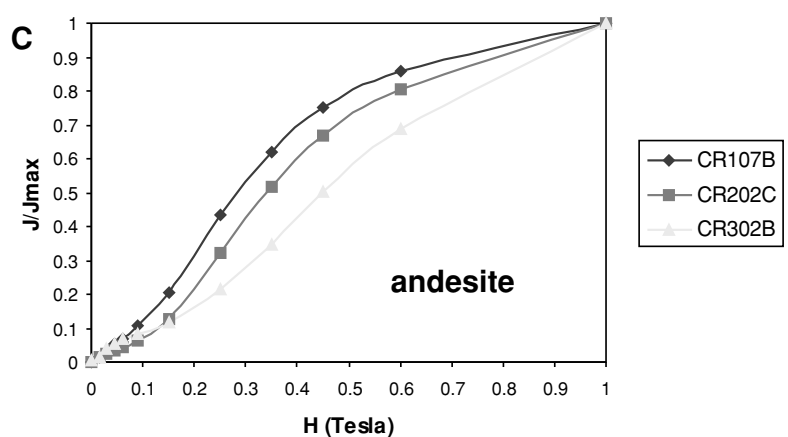

Specimen Susc. (m3/kg) Mrs. (Am2/kg) Mrs/Susc.

$\begin{array}{llll}\text { CR107B } & 7.15 \mathrm{E}-08 & 9.20 \mathrm{E}-08 & 1.29 \mathrm{E}+00 \\ \text { CR202C } & 3.27 \mathrm{E}-08 & 7.51 \mathrm{E}-08 & 2.30 \mathrm{E}+00 \\ \text { CR302B } & 3.21 \mathrm{E}-08 & 5.25 \mathrm{E}-08 & 1.64 \mathrm{E}+00\end{array}$

Fig. 5. IRM acquisition curves from: a) lower member (San Roberto); b) and c) upper member (Río Curacó). Susc. $\left(\mathrm{m}^{3} / \mathrm{kg}\right.$ ): magnetic susceptibility; $\mathrm{Mrs}\left(\mathrm{Am}^{2} / \mathrm{kg}\right)$ : remanent saturation magnetization. Larger values of Mrs indicate increasing dominance of ferromagnetic minerals (Dunlop and Ozdemir, 1997).

IRM acquisition showed that the main carrier of remanence is hematite (indicated by the lack of saturation; Fig. 5b), although the possibility of a mixture of magnetic carriers cannot be discounted.

The high-temperature characteristic remanent magneti- 


\section{Estancia San Roberto}

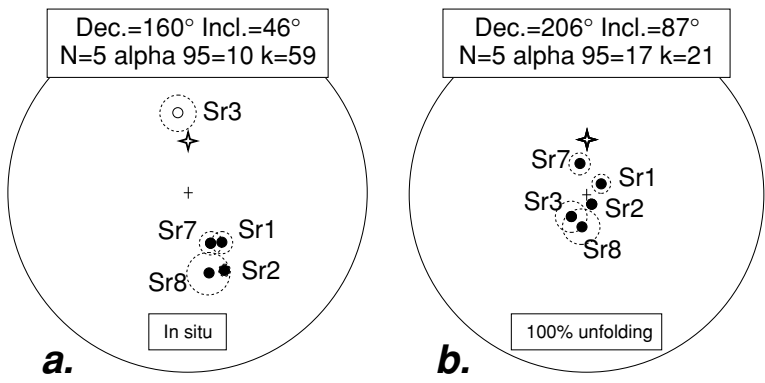

Río Curacó
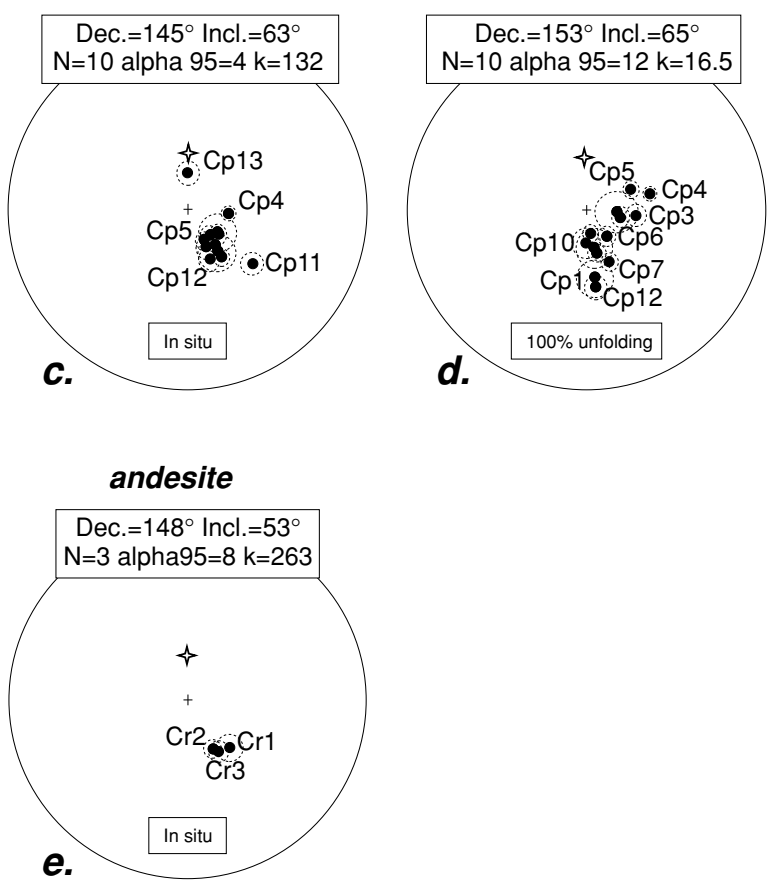

Fig. 6. Remanence directions for population 1 (high-temperature characteristic remanence) in rocks of the Carapacha Basin, equal area projections; left column shows in situ orientations of paleovectors, right column show $100 \%$ tilt-corrected directions. a) and b): lower member of the Carapacha Formation; c) and d): upper member; e): the andesite. See also Table 1. Present field direction indicated by plus symbol, in upper hemisphere. Filled (open) circles are lower (upper) hemisphere reversed (normal) directions.

zation (ChRM) is attributed to "Population 1" (Table 1). It shows positive inclinations (downward directed vectors) and good within-site groupings $\left(\alpha 95<15^{\circ}\right.$ and $\left.\mathrm{k}>20\right)$. Unusual are site $\mathrm{CP} 13$, with negative inclination (in situ) and only one specimen with positive inclination, and sites $\mathrm{CP} 4$ and CP11, with aberrant ChRM directions. Paleomagnetic data from these three sites were rejected. In approximately $90 \%$ of the specimens, a second low temperature component called "Population 2", was isolated between $100^{\circ} \mathrm{C}$ and $450^{\circ} \mathrm{C}$ (Fig. 4b). It has negative inclination (in situ), with northward declination (close to $0^{\circ}$ ) and a tendency to be more scattered. This component is not considered relevant for tectonic purposes.

Unfolding was applied to the Population 1 vectors (Table 1). The in situ mean direction (Fig. 6c) is: $\mathrm{D}=145^{\circ}$, $\mathrm{I}=63^{\circ}, \alpha 95=4^{\circ}, \mathrm{k}=132, \mathrm{~N}=10$. After full bedding correction ( $100 \%$ untilting) the mean direction is: D. $=153^{\circ}$,
$\mathrm{I} .=65^{\circ}, \alpha 95=12^{\circ}, \mathrm{k}=16.5$ (Fig. $6 \mathrm{~d}$ ). This result suggests that the magnetization of the upper Carapacha in this region is also post-folding at $99 \%$ level of confidence (McFadden, 1990). The direction-correction tilt test (Enkin, 2003) yields a negative fold test with an optimal untilting at $-12.3 \pm 25.1 \%$ (Fig. $7 b$ ). The lowblocking temperature in situ mean direction is: D. $=350.5^{\circ}, \mathrm{I} .=-56^{\circ}, \alpha 95=8^{\circ}, \mathrm{k}=35$. This direction is not significantly different from the present geocentric axial dipole field direction $\left(\mathrm{D}=0^{\circ}, \mathrm{I}=-57.5^{\circ}\right)$. The low unblocking temperatures and the proximity to the present day field direction indicate that the Population 2 component is a secondary magnetization of recent vintage.

\section{Paleomagnetic results from the El Centinela andesite at Río Curacó}

Studies were conducted on 22 specimens (21 cores), from 3 sites near La Represa. Natural remanent magnetization ranges around $5 \mathrm{~mA} \mathrm{~m}^{-1}$. In all samples it was possible to isolate one component with positive inclination (Table 1) and good within-site groupings were found $\left(\alpha 95<15^{\circ}\right.$ and $\mathrm{k}>20$ ). This component is attributed to Population 1. Most of the samples were stable during heating with a gradual decay to the origin (Fig. 4d), and unblocking temperatures reached $580^{\circ} \mathrm{C}$, suggesting that this magnetization is carried by titano-hematite or magnetite. The experiments of IRM acquisition showed that the main carriers of the remanence are magnetite, and hematite (indicated by the lack of saturation; Fig. 5c). In sites $\mathrm{Cr} 1$ and $\mathrm{Cr} 2$, a second low temperature component between $100^{\circ} \mathrm{C}$ and $325^{\circ} \mathrm{C}$ was isolated (Fig. 4d). The trend is toward negative inclinations (in situ), with a tendency to be well grouped.

The in situ mean direction for Population 1 vectors (Table 1; Fig. 6e) is: D. $=148^{\circ}, \mathrm{I} .=53^{\circ}, \alpha 95=8^{\circ}, \mathrm{k}=263$, $\mathrm{N}=3$. No bedding correction was applied because the andesite is intrusive, and exhibits no paleo-horizontal reference. The in situ low-temperature component mean direction is: $\mathrm{D}=356^{\circ}, \mathrm{I}=-55^{\circ}, \alpha 95=7^{\circ}$ and $\mathrm{k}=49$. This direction corresponds to the present geocentric axial dipole field direction and is interpreted as a secondary magnetization acquired during recent times.

Computing the Fisher statistics for the best grouping of the acceptable sites for the upper Carapacha and the andesite combined gives a mean with $\mathrm{D}=146^{\circ}, \mathrm{I}=60.5^{\circ}$, $\alpha 95=4^{\circ}, \mathrm{k}=114, \mathrm{~N}=13$ (Table 1).

\section{AMS and Magnetofabrics}

Results of the AMS analyses for the three units studied are summarized in Figs. 8 and 9. AMS axial trends were compared with structural attitudes to evaluate deformation in the area. At locality ESR (Fig. 8b) the rocks of the lower Carapacha member are less deformed than those of the stratigraphically higher member at locality RC. Kmax axes are more variable in trend, plunge down the homoclinal bedding, and do not reflect regional fold trends. Kmin axes plunge about $50^{\circ} \mathrm{S}$, implying bedding dipping about $40^{\circ} \mathrm{N}$ for these strata. The AMS ellipsoid is typically triaxial and the principal AMS axes are well grouped and consistent with bedding orientations. Probably the AMS here reflects the primary depositional fabrics of these fine-grained clastic rocks. 


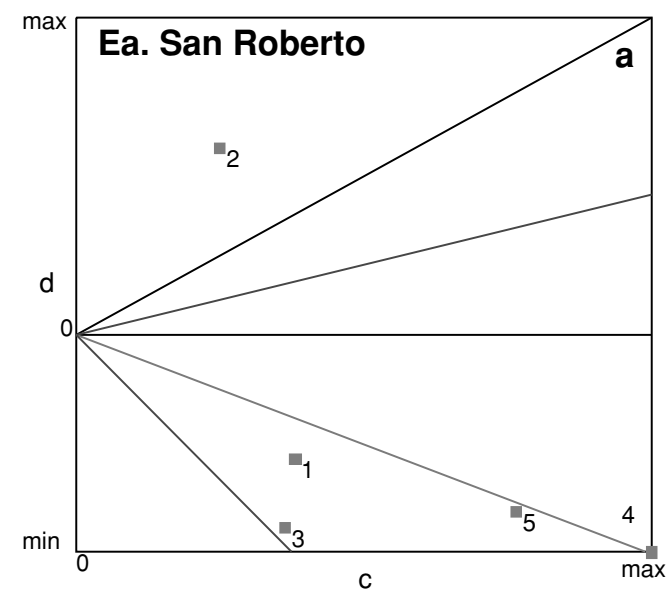

$\begin{array}{lllll}\mathrm{i} & \text { ID } & \mathrm{c} & \mathrm{d} & \mathrm{d} / \mathrm{c} \\ 1 & \mathrm{Sr} 1 & 5.1 & -5.2 & -1.0 \\ 2 & \mathrm{Sr} 2 & 3.3 & 8.0 & 2.39 \\ 3 & \mathrm{Sr} 3 & 4.8 & -8.1 & -1.6 \\ 4 & \mathrm{Sr} 7 & 13.4 & -9.1 & -0.6 \\ 5 & \mathrm{Sr} 8 & 10.3 & -7.4 & -0.7\end{array}$

DC Slope:

$-68.72 \% \pm 113.05 \%$ untilting

Test Negative (Enkin, 2003)

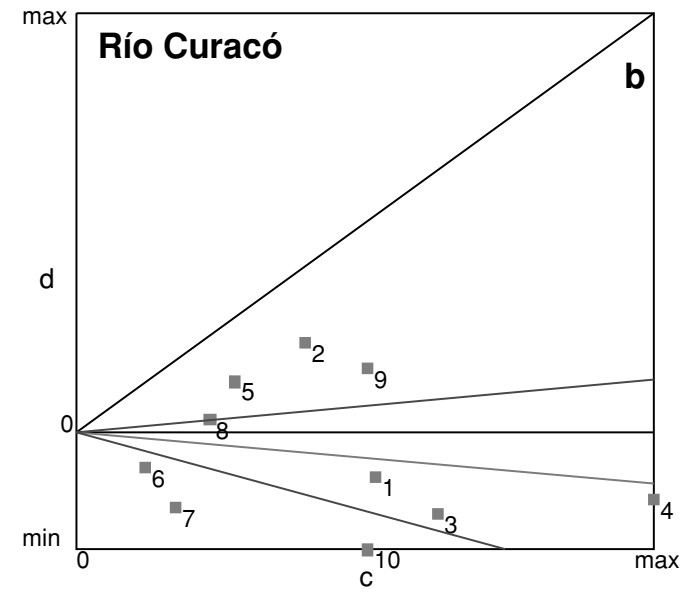

$\begin{array}{ccccl}\mathrm{i} & \mathrm{ID} & \mathrm{c} & \mathrm{d} & \mathrm{d} / \mathrm{c} \\ 1 & \mathrm{cp} 1 & 16.6 & -3.3 & -0.2 \\ 2 & \mathrm{cp} 2 & 12.7 & 7.0 & 0.55 \\ 3 & \mathrm{cp} 3 & 20.1 & -6.2 & -0.3 \\ 4 & \mathrm{cp} 5 & 32.2 & -5.1 & -0.1 \\ 5 & \mathrm{cp} 6 & 8.8 & 4.0 & 0.44 \\ 6 & \mathrm{cp} 7 & 3.8 & -2.7 & -0.7 \\ 7 & \mathrm{cp} 8 & 5.5 & -5.7 & -1.0 \\ 8 & \mathrm{cp} 9 & 7.4 & 1.1 & 0.14 \\ 9 & \mathrm{cp} 10 & 16.2 & 5.0 & 0.30 \\ 10 & \mathrm{cp} 12 & 16.2 & -8.9 & -0.5\end{array}$

DC Slope:

$-12.29 \% \pm 25.13 \%$ untilting

Test Negative (Enkin, 2003)

Fig. 7. Direction-correction tilt-tests (Enkin, 2003). Data sets show clear negative tilt-tests.

In contrast, in the upper Carapacha at locality $\mathrm{RC}$, the $\mathrm{Kmax}$ axes appear to be tectonically related and $\mathrm{Kmin}$ is bimodally distributed (Fig. 8c). Kmax lies close to the fold axes with an average trend of $295^{\circ}$. Some specimens or sites have good consistency between Kmin and the pole of the bedding plane, others show a Kmin consistent with the pole of the axial planes or are transitional between both. This pattern is characteristic of low degree of deformation when Kmax is changing from a primary sedimentary fabric toward the tectonic (secondary) direction of the fold axis. Thus in this area, the AMS magnetofabric reveals a secondary tectonic fabric superimposed on the primary sedimentary one (Tarling and Hrouda, 1993).

The AMS axial ratios (Kmax/Kint and Kint/Kmin) of the upper Carapacha, as well as for the other units of this study, are mainly characteristic of triaxial ellipsoids (Fig. 9). The NW trend of the Kmax axes implies a SW-NE compression. These results are in agreement with available structural data, suggesting a $\mathrm{N} 310^{\circ}$ axial trend of the megafolds (Melchor, 1995). The bimodal distribution in Kmin probably reflects the superimposing of a structural fabric on an earlier sedimentary fabric. The andesitic intrusive does not display a consistent pattern between AMS axes and the magmatic foliation. Kmax is not constant (Fig. 8d) but is mainly distributed in a north-dipping plane. The mean Kmax axis is approximately horizontal and trending
$\mathrm{N} 80^{\circ} \mathrm{W}$, similar to Kmax in the upper Carapacha; this pattern also probably represents a strain effect parallel to regional fold axes. The $\mathrm{F}$ vs. $\mathrm{L}$ and $\mathrm{Pj}$ vs. T diagrams (Jelinek, 1981; Fig. 9) reveal an anisotropy degree mainly below 4\%, with ellipsoids more oblate than prolate.

\section{Discussion}

The upper Carapacha has a characteristic stable secondary post-folding remanent magnetization with exclusively reverse polarity. This is consistent with magnetization being acquired during a long interval of reverse polarity such as the Kiaman reverse superchron. However, as the top of the Kiaman is approximately $266 \mathrm{Ma}$ (Gradstein et al., 2004), this would imply an older age than generally accepted (i.e. not younger than Late Middle Permian). The characteristic direction is a single high-blocking temperature component carried by hematite and magnetite. The associated paleomagnetic pole (PP) was computed from virtual geomagnetic poles (VGP) of the acceptable sites. The best grouping of those vectors in situ were averaged to obtain the upper Carapacha pole: Lat.: $63^{\circ} \mathrm{S}$; Long.: $359^{\circ} \mathrm{E}$, $\mathrm{A} 95=6^{\circ}$ and $\mathrm{K}=73, \mathrm{~N}=10$. The PP calculated for the andesite is: Lat.: $64^{\circ} \mathrm{S}$; Long.: $23^{\circ} \mathrm{E}, \mathrm{A} 95=10^{\circ}$ and $\mathrm{K}=157$, $\mathrm{N}=3$. The average paleomagnetic pole for the upper Carapacha Formation plus the andesite is: Lat.: $64^{\circ} \mathrm{S}$; Long.: $005^{\circ} \mathrm{E}, \mathrm{A} 95=5^{\circ}$ and $\mathrm{K}=68, \mathrm{~N}=13$. In order to simplify the 


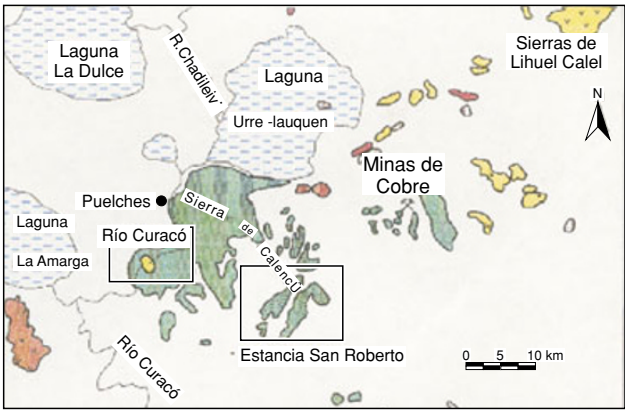

a.

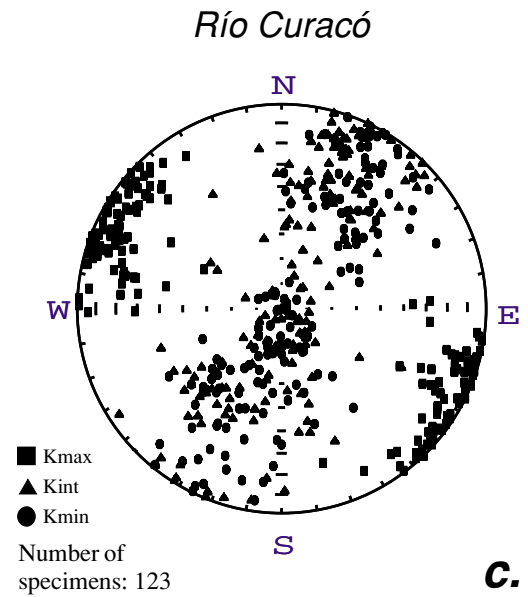

c.

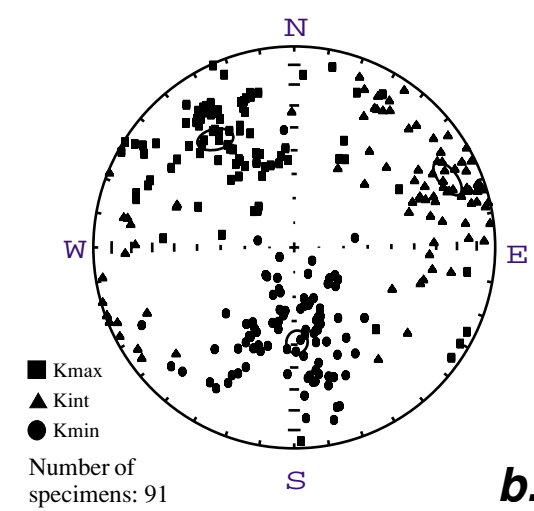

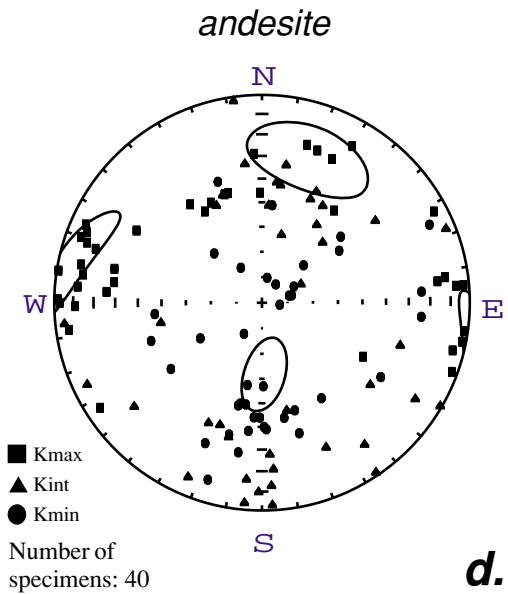

Fig. 8. a) Geologic map shows geologic setting of Carapacha basin and surroundings. Axes of anisotropy of magnetic susceptibility are shown in plots b), c) and d) for the lower member, upper member, and the andesite. Details are given in text. Equal-area projections, lower hemisphere.
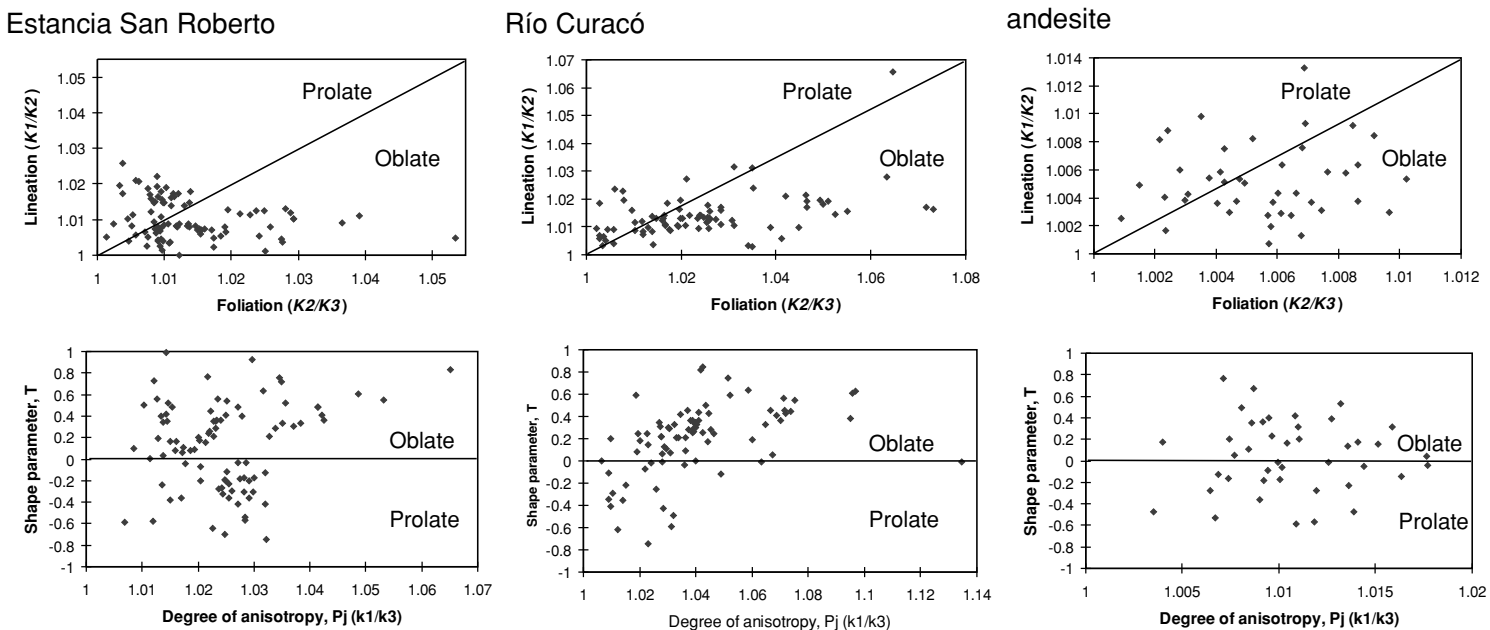

Fig. 9. Flinn-type graphs of AMS axial ratios for foliation vs. lineation (top row) and graphs of shape parameter T vs. degree of anisotropy Pj (bottom row), following Jelinek (1981). Oblate fabrics dominate. Degree of anisotropy is unusually low in the andesite, <2\% (e.g. $<1.02$ ), and higher in the sedimentary rocks of the upper and lower members, mainly in the range of $1 \%$ to about $10 \%$.

nomenclature this PP will be called Río Curacó pole adopting the locality sample name (Table 2; Fig. 10).

The lower Carapacha exhibits also a secondary characteristic stable remanent magnetization, with reverse and normal polarity, this could be consistent with magneti- zation being acquired at the top of the Kiaman. The characteristic direction indicates a single high-blocking temperature component carried by hematite-magnetite or both with the same direction. In this case the magnetization is post-folding. The associated paleomagnetic pole was com- 
Table 2. Late Paleozoic and early Mesozoic South American poles selected from the cratonic areas of South America. PP were taken from Van der Voo (1993) and McElhinny and Lock (1996), Global Paleomagnetic Database, and the data were checked with the original contributions. A95(deg)semi-angle of the 95 per cent confidence cone. The PP were selected based on a minimum of three of the reliability criteria of Van der Voo (1990); see Fig. 10.

\begin{tabular}{|c|c|c|c|c|c|c|c|}
\hline \multirow{2}{*}{$\begin{array}{l}\text { Paleomagnetic } \\
\text { Pole }\end{array}$} & \multicolumn{3}{|c|}{ Site } & \multicolumn{2}{|c|}{ Pole } & \multirow[b]{2}{*}{ Age (PP) } & \multirow[b]{2}{*}{ References } \\
\hline & $\mathrm{A} 95^{\circ}$ & LAT. $^{\circ}$ & LONG. $^{\circ}$ & PLAT. ${ }^{\circ}$ & PLONG. $^{\circ}$ & & \\
\hline SAN ROBERTO & 11 & -38.2 & 294.2 & -70 & 49 & $270-1 \mathrm{P} ?$ & This Work \\
\hline RIO CURACO & 5 & -38.1 & 294.1 & -64 & 005 & 290-1P? & This Work \\
\hline ALTO PARAGUAY & $\operatorname{Pr}$ & 6 & -24 & 302.5 & -78 & 319 & 245-Tr Ernesto (2005) \\
\hline GONZALEZ CHAVES & 17 & -38 & 300 & -84 & 216 & $248.5-\mathrm{Tr}$ & Tomezzoli and Vilas (1997) \\
\hline AMANA Ar & 8 & -30.3 & 292.3 & -83 & 317 & $248.5-1 \mathrm{Tr}$ & Valencio et al. (1977) \\
\hline INDEPENDENCIA Pr & 6.6 & -24 & 304 & -80.7 & 7.0 & 260-uP-lTr & Rapalini et al. (2006) \\
\hline TUNAS II Ar & 5.2 & -38.2 & 298.6 & -74.1 & 25.9 & 275-ulP & Tomezzoli (2001) \\
\hline COCHICO Ar & 17.5 & -34.5 & 293 & -60.3 & 7.4 & 280-1P & Tomezzoli et al. (2005) \\
\hline ITARARE I2 Br. & 4 & -21.5 & 312.8 & -60.3 & 29.5 & 290-1P & Pascholati (1983) \\
\hline TUNAS I Ar. & 5.1 & -38 & 298.2 & -63 & 13.9 & 290-1P & Tomezzoli and Vilas (1999) \\
\hline Lw. COLORADOS Ar & 5 & -29.5 & 293 & -60 & 358 & 293-1P & Embleton (1970) \\
\hline LA COLINA Ar. & 8 & -30 & 293 & -49 & 343 & 294-1P & Sinito et al. (1979) \\
\hline ITARARE I Br. & 4 & -21.5 & 312.8 & -56.7 & 350.6 & 295-1P & Pascholati (1983) \\
\hline TEPUEL Ar. & 8.5 & -43.5 & 289.6 & -31.7 & 316 & $318-1 \mathrm{C}$ & Rapalini et al. (1994) \\
\hline
\end{tabular}

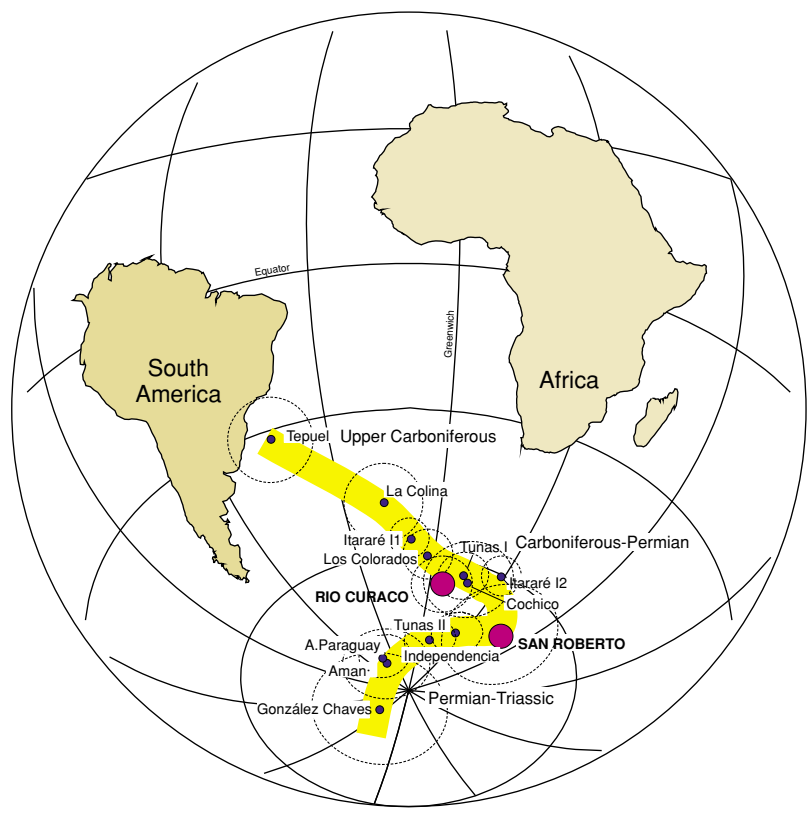

Fig. 10. Paleomagnetic poles from in situ secondary magnetizations in the upper and lower members of the Carapacha formation are shown on the APWP for South America, for the latest Paleozoic to Triassic. Other Late Paleozoic and early Mesozoic South American paleomagnetic poles from the cratonic region are also shown (see Table 2); pps were taken from Van der Voo (1993) and the Global Paleomagnetic Database (McElhinny and Lock, 1996), selected for a minimum of three of the reliability criteria of Van der Voo (1990).

puted from virtual geomagnetic poles (VGP) for each acceptable site's best grouping, in situ: Lat.: $70^{\circ} \mathrm{S}$; Long.: $49^{\circ} \mathrm{E}, \mathrm{A} 95=11^{\circ}$ and $\mathrm{K}=52, \mathrm{~N}=5$ (Table 2; Fig. 10). This PP will be called San Roberto adopting the locality sample name (Table 2; Fig. 10).

The pattern of magnetizations suggests that the Carapacha strata were remagnetized after folding. The positions of the poles are compared with the Late Paleozoic apparent polar wander path (APWP) of South America in Fig. 10 and Table 2. In time their positions imply ages of late Early
Permian to early Late Permian. The position on the APWP suggests that although San Roberto is chronologically older, its magnetization age may be younger than those of the Río Curacó, consistent with the differences in their AMS magnetofabrics. The proposed interpretation is that orogenic activity has affected the upper section more strongly, probably in a left-lateral strike-slip regime (Melchor, 1995). This inference is made on the basis of the angular relationships of mega-and mesostructural features (folds, faults and extensional veins). The main strike-slip zone is inferred to have a $\mathrm{N} 60^{\circ} \mathrm{W}$ orientation, which is closely parallel to an older, Early Paleozoic structural fabric in the region (Linares et al., 1980; Llambías et al., 1996). In the andesite intrusive into the upper Carapacha, the AMS pattern is not too different from that in the host rocks (Fig. 8c, d), suggesting perhaps a lighter tectonic imprint in the stronger massive intrusion.

The characteristic in situ paleomagnetic directions for both members of the Carapacha Formation are post-folding. The main differences between the lower and upper members of the Carapacha Formation are the intensity of the deformation, the position in the stratigraphic column, and the position of the in situ PPs in the APWP. The older deposits are less deformed than the younger deposits. The Río $\mathrm{Cu}-$ racó pole (Fig. 10) represents an older Permian position in the APWP than that of the San Roberto. The overprint in the Río Curacó could be related to the intrusion of the andesite during the San Rafael orogeny (Azcuy and Caminos, 1987).

Remagnetization of the San Roberto could be related to the ubiquitous rhyolitic volcanism of the area or possibly to younger geologic events. Mineralized veins in the nearby mining district of Lihuél Calel (about $20 \mathrm{~km}$ northeast of the ESR locality; see map Fig. 6a) display a preferred orientation of $\mathrm{N} 40^{\circ} \mathrm{E}-\mathrm{N} 60^{\circ} \mathrm{E}$ with steep NW dips (Malvicini and Delpino, 1987). The mineralization is hydrothermal and envisaged as a final episode of the Choiyoi volcanism. Geophysical surveys suggest that the mineralized area extends southwest towards the San Roberto vicinity (Melchor, 
1995). Thus it is possible that this hydrothermal event remagnetized rocks of the San Roberto region; such remagnetization should be younger than $266 \mathrm{Ma}$ (i.e, post-Kiaman). This is the approximate age of eruption for the rhyolitic volcanic province in the region (Rapela et al., 1996).

The possibility of a Triassic (or younger) age for the secondary magnetizations presents a dilemma. The younger poles of the APWP are mainly south of the site and closer to the present-day pole, ie. relative to the Carapacha sites, they are clockwise. It seems implausibly coincidental that local tectonic rotations of three rock units would be precisely of the sense and amount to place younger poles exactly in late Permian positions along the APWP. Therefore it is unlikely that local structural rotations of younger poles explain these Carapacha poles.

The declination difference for the Río Curacó and San Roberto poles from the sampling region is $14^{\circ} \pm 9^{\circ}$; and the difference in latitudes of the sites relative to the two poles is $14^{\circ} \pm 8$, significant at the $95 \%$ confidence level. The apparent age difference between the two poles, as judged by their relative positions along the APWP, is too large to attribute the declination difference to secular variation. The presence of reversed components in the lower Carapacha rocks, although secondary, also argues against a secular variation explanation. Unresolved differences in post-tectonic tilt, towards NW and SE, between the two regions might explain the latitudinal differences, but geologic evidence for this is lacking. The $14^{\circ} \pm 9^{\circ}$ declination difference might reflect local rotation after the main deformation; however such rotation is marginally significant. Preliminary results from work in progress on El Centinela type area indicates also a bimodal pole distribution similar to that of the present study and possibly will help clarify the interpretation of this phenomenon (Tomezzoli, 2005).

Our results are consistent with the regional tectonic pattern developed in the area of Sierra de la Ventana, $300 \mathrm{Km}$ to the east (Fig. 1). The rocks of the lower and upper Tunas Formation were magnetized or remagnetized at different stages of the tectonic cycle between the Lower Permian and the Lower Upper Permian. Remagnetization is synfolding in the western area of the Tunas depositional basin (Tunas I paleopole; Tomezzoli and Vilas, 1999) near the fold and thrust belt, but is prefolding near the foreland (Tunas II paleopole; Tomezzoli, 2001). The Tunas I and Tunas II poles paleogeographic implications are consistent with a counterclockwise movement of the continent between the Early and Late Permian. Geological evidence indicates that sedimentation in Sierra de la Ventana was partially coeval with deformation (Cobbold et al., 1991) and that deformation advanced from west to east. López Gamundi et al. (1995) interpreted this deformation and the coeval foreland basin phase as affecting diachronously the entire Panthalassan margin, ranging from Early Permian in western Argentina, slightly later in South Africa to Late Permian in eastern Australia (Veevers et al., 1994).

The Rio Curacó (post-tectonic magnetization) and Tunas I pole (syntectonic magnetization) are concordant with other Early Permian deformation-related PPs in the APWP of South America (Fig. 10). Possibly the prominent $90^{\circ}$ bend in the APWP reflects an important deformation event in Gondwana history. The paleogeographic implications of these results are interpreted as a significant counterclockwise movement of Gondwana between the early and the late Permian. Although in the Carapacha Basin (west), magnetizations are post-folding, those in Sierra de la Ventana (east) are pre-and synfolding. The pattern of remagnetization and folding indicates that folding and remagnetizaiton occurred during a relatively short period of time as the orogenic front propagated toward the foreland. The San Roberto pole of this study is thought to represent a remagnetization age younger than the Rio Curacó and Tunas I poles.

Differences in the AMS response between the two members of Carapacha Formation are consistent with their lithologic and structural features. Their magnetofabrics are associated with an orogenic phase, possibly the San Rafael orogeny (Azcuy and Caminos, 1987; Ramos, 1988) that produced a paleogeographic reorganization during the Early Permian-Late Permian. The Early Permian deformation phase, responsible for the magnetization described in Carapacha Basin and in the Sierra de la Ventana (Tomezzoli and Vilas, 1999) has been recognized mainly in western Argentina (Llambías and Sato, 1995) and was linked previously to regional scale remagnetizations (Rapalini and Tarling, 1993).

\section{Conclusions}

This paleomagnetic study of the Carapacha Basin of central Argentina shows that the sedimentary rocks of the Carapacha Formation has post-folding magnetizations. From them, two paleomagnetic poles were determined: 1) from the lower part of the formation, in San Roberto the pole is Lat.: $70^{\circ} \mathrm{S}$; Long.: $49^{\circ} \mathrm{E}, \mathrm{A} 95=11^{\circ}$ and $\mathrm{K}=52, \mathrm{~N}=5$; and 2 ), from the upper part of the formation, by combining results from an intrusive andesite, Río Curacó pole is: Lat.: $64^{\circ} \mathrm{S}$; Long.: $005^{\circ} \mathrm{E}, \mathrm{A} 95=5^{\circ}$ and $\mathrm{K}=68, \mathrm{~N}=13$.

These new PPs lie on the South American APWP; Carapacha remagnetizations and paleomagnetic poles thus correspond to events in the late Early Permian to early Late Permian interval, soon after sedimentation. The dominant characteristic magnetizations are post-folding for this part of the Gondwánides belt, as compared to pre- and synfolding further east. The pattern of remagnetization and folding indicates that the rocks were remagnetized and folded during a relatively short period of time as the orogenic front propagated eastward toward the foreland. According to these results, deformation, possibly involving collision between Patagonia and the South American craton, began during the Devonian in the west and propagated eastward until the Permian. The paleogeographic implications of these results are interpreted as a significant counterclockwise movement of Gondwana between the early and the late Permian. This deformative episode probably marked a late adjustment between the continental blocks before the final assembly of Pangea.

Acknowledgments. All processing was carried out using the following software: Criolapd and Estereográfica-GR (E. O. Cristallini); IAPD (T. H. Torsvik); Cirdi (M. Mena); Mag88 (E. Oviedo); APLOT10 (modified by B. Lienert). PMGSC: Paleomagnetic data analysis (R. Enkin). We are especially grateful to E. Cristallini for his invaluable collaboration during all phases of 
this work. C. Vazquez is thanked for help with IRM analysis and for the continuous maintenance of the equipment. R. Enkin is thanked for help with the use of PMGSC program. A. Goldstein of Colgate University kindly provided access to equipment for AMS measurements. We thank the editor and the reviewers J. Dinarès-Turell and other for help and constructive reviews. Field work was funded by project $118 / \mathrm{CN}$ from the Universidad de La Pampa. R N Tomezzoli acknowledges support through PEI and PIP-CONICET and Fundación Antorchas: Subsidio de Apoyo a Proyectos.

\section{References}

Azcuy, C. L. and R. Caminos, Diastrofismo, in El Sistema Carbonífero en la República Argentina, edited by S. Archangelsky, Academia Nacional de Ciencias, Córdoba, pp. 239-251, 1987.

Cobbold, P. R., D. Gapais, and E. A. Rossello, Partitioning of transpressive motions within a sigmoidal foldbelt: the Variscan Sierras Australes, Argentina, Journal of Structural Geology, 13(7), 743-758, 1991.

Cobbold, P. R., D. Gapais, E. A. Rossello, E. Milani, and P. Szatmari, Permo-Triassic intracontinental deformation in SW Gondwana, in Inversion Tectonics of the Cape Fold Belt, Karoo and Cretaceous Basins of Southern Africa, edited by W. Ransome, pp. 23-26, Balkema, Rotterdam, 1992.

Dalmayrac, B., G. Laubacher, R. Marocco, C. Martinez, and P. Tomasi, La chaine hercynienne d'Amerique du Sud. Structure et evolution d'un orogene intracratonique, Sonderdruck a.d. Geol. Rundschau, 69(1),121, Stuttgart, 1980.

Dunlop, D. J. and Ö. Özdemir, Rock Magnetism. Fundamentals and Frontiers, Cambridge University Press, 573 pp., Cambridge, 1997.

Du Toit, A., A geological comparison of South America with South Africa, Carnegie Institute of Washington Publications, 381, 1-157. Washington, 1927.

Embleton, B. J. J., Paleomagnetic results for the Permian of South America and a comparison with the African and Australian data, Geophysical Journal Royal astronomical Society, 21,105-118, 1970.

Enkin, J. R., The direction-correction tilt test: an all-purpose tilt/fold test for paleomagnetic studies, Earth and Planetary Science Letters, 212, 151-166, 2003

Ernesto, M., New Early Triassic Paleomagnetic Pole for South America from the Alto Paraguay Alkaline Province, 2005 Joint Assembly AGU, New Orleans, USA, Abstracts: GP-41A-08, 2005.

Fisher, R. A., Dispersion on a sphere, Proceedings Royal Society of London, A217, 295-305, 1953.

Gradstein, F., J. Ogg, and A. Smith, A Geologic Time Scale 2004, Cambridge University Press, New York, 589 pp., 2004.

Halls, H. C., A least squares method to find a remanence direction from converging remagnetization circles, Geophysical Journal of the Royal Astronomical Society, 45, 297-304, 1976.

Japas, M. S., La deformación de la cadena plegada de las Sierras Australes de la provincia de Buenos Aires, Anales de la Academia Nacional de Ciencias Exactas Físicas y Naturales, 40, 193-215, Buenos Aires, 1989.

Jelinek, K., Characterization of the magnetic fabric of rocks, Tectonophysics, 79, 63-67, 1981 .

Kay, S. M., V. A. Ramos, C. Mpodozis, and P. Sruoga, Late Paleozoic to Jurassic silicic magmatism at the Gondwana margin: Analogy to the Middle Proterozoic in North America?, Geology, 17, 324-328, 1989.

Keidel, J., La geología de las sierras de la Provincia de Buenos Aires y sus relaciones con las montañas del Cabo y los Andes, Ministerio de Agricultura Nacional, Anales Dirección Nacional de Geología y Mineria. IX (3), Buenos Aires, 1916.

Kirschvink, J. L., The least squares line and plane and the analysis of paleomagnetic data, Geophysical Journal Royal Astronomical Society, 62, 699-718, 1980 .

Linares, E., E. J. Llambías, and C. O. Latorre, Geología de la provincia de La Pampa, República Argentina y Geocronología de sus rocas metamórficas y eruptivas, Revista de la Asociación Geológica Argentina, 35(1), 87-146, 1980.

Llambías, J. E. and A. M. Sato, El batolito de Colanguil: transición entre orogénesis y anorogénesis, Revista de la Asociación Geológica Argentina, 50(1-4), 111-131, 1995.

Llambías, E. J., R. N. Melchor, H. Tickyj, and A. M. Sato, Geología del Bloque del Chadileuvú. XIII Congreso Geológico Argentino y III Congreso de Exploración de Hidrocarburos, Actas V, 417-425, Buenos Aires, 1996.
López Gamundi, O. R., P. J. Conaghan, E. A. Rosello, and P. R. Cobbold, The Tunas Formation (Permian) in the Sierras Australes Foldbelt, east central Argentina: evidence for syntectonic sedimentation in a foreland basin, Journal of South American Earth Sciences, 8(2), 129-142, 1995.

Malvicini, L. and D. H. Delpino, Metalogénesis de los complejos riolíticos de la provincia geológica Sanrafaelino Pampeana y la Comarca Nordpatagónica, Argentina. X Congreso Geológico Argentino, 5, 63-82, S. M. de Tucumán, 1987.

McElhinny, N. W. and J. Lock, IAGA paleomagnetic databases, Access Surv. Geophys., 17, 575-591, 1996.

McFadden, P. L., A new fold test for paleomagnetic studies, Geophysical Journal International, 103, 163-169, 1990.

McFadden, P. L. and N. W. McElhinny, The combined analysis of remagnetization circles and direct observations in paleomagnetism, Geophysical Journal International, 103, 725-729, 1988.

Melchor, R. N., Sedimentología de las unidades paleozoicas aflorantes del centro-oeste de la provincia de La Pampa, Argentina. Universidad Nacional de La Plata. Tesis doctoral inédita, 272 pp., La Plata, 1995.

Melchor, R. N., Redefinición estratigráfica de la Formación Carapacha (Pérmico), Provincia de La Pampa, Argentina, Revista de la Asociación Geológica Argentina, 54, 99-108, 1999.

Melchor, R. N. and E. J. Llambías, Descripción de la Hoja Geológica 3766 1 "Santa Isabel". Provincia de La Pampa, Servicio Geológico Minero Argentino, 48 pp. (unpublished), 2000.

Melchor, R. N. and S. N. Césari, Algunos elementos paleoflorísticos de la Formación Carapacha (Pérmico inferior), provincia de La Pampa, República Argentina, Ameghiniana, 28, 347-352, 1991.

Melchor, R. N. and S. N. Césari, Permian floras from Carapacha Basin, La Pampa Province, central Argentina. Description and importance, Geobios, 30(5), 607-633, 1997.

Pascholati, E. M., Possibilidade de interferencias termais do magnetismo Juro-cretácico na analise paleomagnética do Grupo Itarare, Atlas do 4 Simposio Regional de Geologia, SBG: 211-222, Sao Paulo, 1983.

Ramos, V. A., Patagonia: un continente paleozoico a la deriva?, $9^{\circ}$ Congreso Geológico Argentino, Actas II, S. C. Bariloche, Buenos Aires, 311-325, 1984.

Ramos, V. A., Tectonics of the Late Proterozoic Early Paleozoic: a collisional history of Southern South America, Episodes, 11(3), 168-174, Ottawa, 1988.

Rapalini, A. E. and D. H. Tarling, Multiple magnetizations in the Cambrian-Ordovician carbonate platform of the Argentine Precordillera and their tectonic implications, Tectonophysics, 227, 49-62, 1993.

Rapalini, A. E., D. H. Tarling, P. Turner, S. Flint, and J. F. Vilas, Paleomagnetism of the Carboniferous Tepuel Group, central Patagonia, Argentina, Tectonics, 13(5), 1277-1294, 1994.

Rapalini, A. E., S. Fazzito, and D. Orué, A new Late Permian paleomagnetic pole for stable South America: the Independencia Group, Paleomagnetism in Latinoamerica, Earth Planets Space, 58, this issue, $\mathrm{xxx}-$ xxx, 2006

Rapela, C. W., R. J. Pankhurst, E. J. Llambías, C. Labudía, and A. Artabe, "Gondwana" magmatism of Patagonia: Inner cordilleran calc-alkaline batholiths and bimodal volcanic provinces, Proceedings Third International Symposium on Andean Geodynamics, 791-794, Saint Malo, 1996.

Sellés Martinez, J., The structure of Sierras Australes (Buenos Aires, Argentina). An example of folding in a transpressive environment, Journal of South America Earth Science, 2(4), 317-329, 1989.

Sinito, A. M., D. A. Valencio, and J. F. Vilas, Paleomagnetism of a sequence of Upper Paleozoic-Lower Mesozoic red beds from Argentina, Geophysical Journal Royal astronomical Society, 58, 237-247, 1979.

Tarling, D. H. and F. Hrouda, The Magnetic Anisotropy of Rocks, edited by Chapman \& Hall, London, Se1 8 Hn., 217 p, 1993.

Tickyj, H., Estructura y petrología del basamento cristalino de la región centro-sur de la provincia de La Pampa, Argentina. Tesis Doctoral. Universidad Nacional de La Plata, 228. La Plata, Unpublished, 1999.

Tickyj, H., E. J. Llambías, and A. M. Sato, El basamento cristalino de la región sur-oriental de la provincia de La Pampa: Extensión austral del Oróeno Famatiniano de Sierras Pampeanas, 14th Congreso Geológico Argentino, Actas 1, 160-163, 1999.

Tomezzoli, R. N., Further paleomagnetic results from the Sierras Australes fold and thrust belt, Argentina, Geophysical Journal International, 147, 356-366, 2001.

Tomezzoli, R. N., Paleogeography of Southwest Gondwana boundary during the Upper Paleozoic, Eos Trans. AGU, 86(18), Jt. Assem. Suppl., Abstract GP41A-03, 2005 . 
Tomezzoli, R. N. and J. F. Vilas, Paleomagnetismo y fábrica magnética en afloramientos cercanos a las Sierras Australes de la Provincia de Buenos Aires (López Lecube y González Chaves), Revista Asoc. Geol. Argentina, 52(4), 419-432, 1997.

Tomezzoli, R. N. and J. F. Vilas, Paleomagnetic constraints on age of deformation of the Sierras Australes thrust and fold belt, Argentina, Geophysical Journal International, 138, 857-870, 1999.

Tomezzoli, R. N. and R. N. Melchor, Estudio paleomagnético preliminar en el miembro superior de la Formacion Carapacha, provincia de La Pampa. $19^{\circ}$ Reunión de la Asociación Argentina de Geofísicos y Geodestas. 1as, Jornadas de Catastro Minera, I, 106-110, San Juan, 1997.

Tomezzoli, R. N., W. D. MacDonald, and H. Tickyj, Composite magnetic fabrics from S-C granitic gneiss of Cerro de los Viejos, La Pampa province, Argentina, Journal of Structural Geology, 25/2, pp. 159-169, 2003.

Tomezzoli, R. N., L. Kleiman, J. Salvarredi, C. Terrizzano, and E. O. Cristallini, Paleogeographic evolution of the Southwest Gondwana boundary during the late Paleozoic. Paleomagnetism of the lower Choiyoi volcanics in the San Rafael block, Mendoza, Argentina. ISAG. Extended Abstracts, 730-733. Barcelona, 2005.
Valencio, D. A., J. F. Vilas, and J. E. Mendia, Paleomagnetism of a sequence of red beds of the middle and the upper sections of Paganzo Group (Argentina) and the correlation of upper Paleozoic-lower Mesozoic rocks, Geophysical Journal Royal astronomical Society, 51, 59-74, 1977.

Van der Voo, R., The reliability of paleomagnetic data, Tectonophysics, 184, 1-9, 1990

Van der Voo, R., Paleomagnetism of the Atlantic, Tethys and lapetus Oceans, Cambridge University Press, pp. 411, 1993.

Veevers, J. J., C. McA. Powell, J. W. Collinson, and O. R. López Gamundí, Synthesis, in Permian-Triassic Basins and Foldbelts along the Panthalassan Margin of Gondwanaland, edited by J. J. Veevers and McA. Powell, Geol. Soc. of America. Memoir, 184, 331-354, 1994.

Zijderveld, A. C., Demagnetization of rocks: Analysis of results, in Methods in Paleomagnetism, edited by D. W. Collinson, K. M. Creer, and S. K. Runcorn, Elsevier, pp. 254-286, Amsterdam, 1967.

R. N. Tomezzoli (e-mail: renata@gl.fcen.uba.ar), R. N. Melchor (email: r_melchor@exactas.unlpam.edu.ar), and W. D. MacDonald (e-mail: wdmacdon@binghamton.edu) 